\title{
SUAUGUSIŲ ŽMONIŲ DANTŲ GYDYMO BAIME LEMIANTYS INDIKATORIAI
}

\author{
Karolis Vasiliauskas, Kristina Klasavičiūtė, Ingrida Vasiliauskienė, Vilija Andruškevičienė, \\ Kristina Saldūnaitė, Eglè Slabšinskienè \\ Lietuvos sveikatos mokslu universiteto Medicinos akademijos Odontologijos fakultetas
}

Raktažodžiai: dantų gydymo baimè, odontologo baimè.

\section{Santrauka}

Tyrimo tikslas. Išsiaiškinti suaugusių žmonių pagrindinius dantų gydymo baimę lemiančius veiksnius. Tyrimo medžiaga ir metodai. Vienmomentinis tyrimas vykdytas Kauno centro poliklinikoje bei Vilkaviškio PSPC. Apklausti šiose įstaigose gydęsi pacientai. Pildytos anketos, nagrinejjančios demografinę charakteristiką, elgesị, socialinius bei ekonominius veiksnius. Siekiant nustatyti, ar visi klausimyno klausimai atitinka anketos turinị ir išsikeltą hipotezę, buvo pasirinktas Cronbach alfa koeficientas. Statistine analizė buvo atlikta naudojant SPSS 22.0 programą. Pasirinktas statistinio patikimumo lygmuo, kai $p<0,05$. Kiekybiniai kintamieji buvo išreikšti vidurkiais su standartiniu nuokrypiu $\mathrm{V}(\mathrm{SD})$ su 95 proc. patikimumo intervalu. Priklausomybè tarp kokybinių parametrų buvo ivvertinta remiantis $\chi^{2}$ kriterijumi.

Rezultatai. Tyrime dalyvavo 148 pacientai: 96 moterys ir 52 vyrai. Daugiau nei puse $(55,9$ proc.) apklaustųjų nurodo bijantys dantų gydymo, iš jų 9,5 proc. - labai. Stipriau dantų gydymo bijo moterys nei vyrai. Didesnę baimę jaučia išsiskyrę asmenys (71,4 proc.) nei vedę ar vieniši. Dažniau ị odontologą kreipiamasi, kai skauda. Dominuojanti organizmo reakcija - noras išvengti vizito. Baimè yra kiekvieną kartą lankantis pas odontologą ir daugiau žmonių bijo dantų šalinimo procedūros, o didžiausia baimè yra matant adatą - 56 proc. apklaustujjų.

Išvados. 56,1 proc. apklaustuju patiria odontologinę baimę, iš jų net 9,5 proc. - labai stiprią baimę, dèl kurios vengia odontologinių procedūrų. Lytis, išsilavinimas, gyvenamoji vieta neturejo ịtakos baimei. Odontologinei baimei ịtakos turèjo amžius, šeimyninè padètis, pirmas vizitas pas odontologą. Baimè reikšmingai padidèja, kai reikia ilgai laukti ir šalia yra blogai nusiteikusių pacientų. 61,4 proc. bijančiujų kreipiasi, kai skauda, 9,6 proc. - kai skausmas yra nebepakeliamas. Daugiausia žmonių bijo šalinti, gręžti dantis, matyti adatą ir jausti adatos įdūrimą.

\section{Ivadas}

Dantų gydymo fobijos, dantų gydymo baimés ir dantų gydymo nerimo terminai odontologijos literatūroje naudojami apibūdinti diskomfortui, kurị pacientai patiria lankydamiesi odontologo kabinete dantų priežiūros procedūrų [1]. Daugelis žmonių, lankydamiesi šiose ịstaigose, jaučia baimę ir nerimą [2]. Nustatyta, kad nuo 6 iki 15 procentų žmonių vengia reguliaraus apsilankymo pas odontologą dèl baimès. Net 40 procentų žmonių pasaulyje turi dantų gydytojo baimę, o net 5 proc. pripažista ją kaip fobiją [3]. Daugiau nei 20 proc. pacientų turi padidejjusią baimę, iš kurių 12,3 proc. nurodè vidutinę baimę ir 8,75 proc. didelę baimę [4]. Australijoje atlikti tyrimai parodè, kad dantų gydymo baimę turi nuo 7,8 iki 18,8 proc., o fobiją - nuo 0,9 proc. iki 5,4 proc. $[5,6]$. Atlikto tyrimo metu šiaurès vakarų Anglijoje buvo nustatyta, kad iš tirtų 1420 suaugusiujų, pusé iš jų nurode, kad jų odontologo baimė atsirado dar vaikystejje [7]. Literatūros duomenimis, didesnę dantų gydymo baimę jaučia moterys, žemesnị išsilavinimą turintys, mažesnes pajamas gaunantys apklaustieji, vyresni žmonès $[7,8]$. Suomijoje dantis gydyti labiau bijojo 35-54 metų amžiaus asmenys [9]. Adatų (46 proc.) ir skausmingos injekcijos bijo (42,9 proc.) apklaustujų [6]. Lietuvoje tik nuo 2003 metu paskelbti straipsniai, nagrinejjantys vaikų dantų gydymo baimę. Suaugusių žmonių dantų gydymo baimès problema iki šiol nebuvo nagrinèta.

Tyrimo tikslas: išsiaiškinti suaugusių žmonių pagrindinius dantų gydymo baimę lemiančius veiksnius.

\section{Tyrimo medžiaga ir metodai}

Vienmomentinis tyrimas atliktas, gavus LSMU Bioetikos komiteto leidimą Nr. BEC-OF-51. Buvo atrinkti pacientai, besilankantys Kauno centro poliklinikoje bei Vilkaviškio 
pirminès sveikatos priežiūros centre. Pateikta anketa apie dantų gydymo baimę. Anketoje buvo nagrinèjamos 4 klausimų grupès: demografinès charakteristikos (apklausiamujų amžius, lytis, gyvenamoji vieta), elgesio veiksniai (nuo kelerių metų lankosi pas odontologą, kaip dažnai lankosi, kokia lankymosi priežastis, ar bijo), konkrečių dantų dirgiklių ir procedūrų baimè vertinta remiantis dantų gydymo baimès skale [10], socialiniai ir ekonominiai veiksniai (klausimai apie išsilavinimą, pajamas, šeiminę padèti). Siekiant nustatyti, ar visi klausimyno klausimai atitinka anketos turinį ir išsikeltą hipotezę, buvo pasirinktas Kronbacho (Cronbach) alfa koeficientas, kuris parodo, kaip kinta tiriamujų atsakymai ị tuos pačius klausimus. Apskaičiuotas Kronbacho alfa koeficientas, kurio reikšmė gauta 0,94 - rodo aukšto lygio klausimyno patikimumą [11].

Statistinè analizè buvo atlikta naudojant statistiniu duomenų analizės paketą, SPSS 22.0 programą. Pasirinktas statistinio patikimumo lygmuo, kai $p<0,05$. Atliekant aprašomają analizę, kiekybiniai kintamieji buvo išreikšti vidurkiais su standartiniu nuokrypiu $\mathrm{V}(\mathrm{SD})$ su 95 proc. patikimumo intervalu. Priklausomybe tarp kokybinių parametrų buvo ịvertinta remiantis $\chi^{2}$ kriterijumi. Dviejų nepriklausomų grupių kiekybiniams dydžiams palyginti buvo taikomas Stjudento (Student) (t) kriterijus. Vienpusé dispersinè analizé (ANOVA) buvo naudota lyginant kiekybinius duomenis, esant daugiau nei dviem nepriklausomoms grupems. Kai kintamieji netenkino pasiskirstymo normališkumo sąlygos (buvo ranginio pobūdžio), buvo taikomi neparametriniai statistiniu hipotezių tikrinimo metodai - Mano Vitney (Mann-Whitney) U (kintamajam tarp dviejų grupių palyginti) ir Kruskalio Voliso (Kruskal-Wallis) K (kintamajam tarp daugiau nei dviejų grupių palyginti).

Rezultatai ir aptarimas. Tyrime dalyvavo 148 pacientai: 96 (64,9proc.) moterys ir 52 (35,1 proc.) vyrai. Pacientu amžius buvo nuo 18 iki 65 metų. 68,2 proc. tirtujų buvo miesto ir 31,8 proc. - rajono gyventojai. Pagal išsilavinimą: 32,4 proc. vidurinis, 14,2 proc. - profesinis, 26,4 proc. - aukštesnysis, 27 proc. aukštasis išsilavinimas. 54,7 proc. buvo vedę ar ištekejjusios, 14,2 proc.- išsiskyrę, 30,4 proc. vieniši. 4,7 proc. pas odontologą lankosi nuo 2 metų, 22,3 proc. nuo $3-5$ metų, 35,1 proc. nuo 7-10 metų, 9,5 proc. nuo 12 metų ir 28,4 proc. - neprisimena. Po apklausos paaiškejjo, kad 70,9 proc. gydosi privačioje praktikoje ir 29,1 proc. valstybineje. 37,8 proc. lankosi, kai skauda, 29,1 proc.- 1 kartą per metus, 26 proc.- 2 kartus per metus, kas 2 metai -17 proc., kas 5 metai -6 proc. 77,7 proc. apklaustuju yra svarbi gydytojo empatinè charakteristika, 17,6 proc. - klinika, 4,7 proc. - viskas. 53,4 proc. vizitas būna kai skauda, 40,5 proc. - profilaktinis ir 6,1 proc. kreipiasi tik tada, kai skausmas būna nebepakeliamas.

56,1 proc. apklaustujų bijo dantu gydymo, 43,9 proc. - nebijo. Iš 56,1 proc. bijančiųjų - 9,5 proc. patiria labai didelę dantų gydymo baimę [1 pav.]. Apklaustieji, kurie nebijo dantų gydymo, statistiškai reikšmingai pas odontologą pradèjo lankytis anksčiau $\left(\chi^{2}=12,98,11 \mathrm{~s}=4, \mathrm{p}=0,011\right)$ [2 pav.].

55,4 proc. nebijančiujų vizitas pas odontologą būna profilaktinis, 61,4 proc. bijančiujų kreipiasi tik tada, kai skauda ir 9,6 proc. bijančiujų - kai skausmas nebepakeliamas $\left(\chi^{2}\right.$ $=12,53,11 \mathrm{~s} .=2, p<0,05)[3$ pav.]. Koks yra gydytojas statistiškai reikšmingai svarbiau nebijantiems (84,6 proc.) nei bijantiems ( 72,3 proc. $)\left(\chi^{2}=3,20,11 \mathrm{~s}=2, \mathrm{p}<0,05\right)$ pacientams.

Belaukiant vizito pas odontologą daugiau nei pusè pacientų norètų išvengti vizito, trečdaliui - prakaituoja delnai, 4,1 proc. - darosi silpna, 6,8 proc. - pakyla kraujo spaudimas.

Apklausus, kada jaučiama didžiausia baimè, paaiškèjo kad: 30,4 proc. pacientų jaučia didelę baimę, kai bus atliekama jam nežinoma procedūra, 23,6 proc. - pirmo apsilankymo metu, 18,2 proc. kiekvieną kartą, 18,2 proc. žmoniu jaučiasi nemaloniai, kai procedūras atliks naujas, nepažįs-

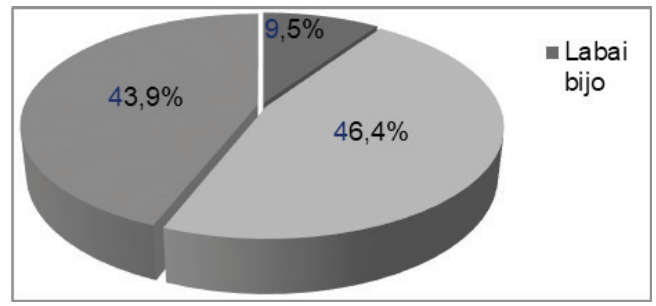

1 pav. Suaugusiujų pasiskirstymas (proc.) pagal patiriamą dantų gydymo baimę.

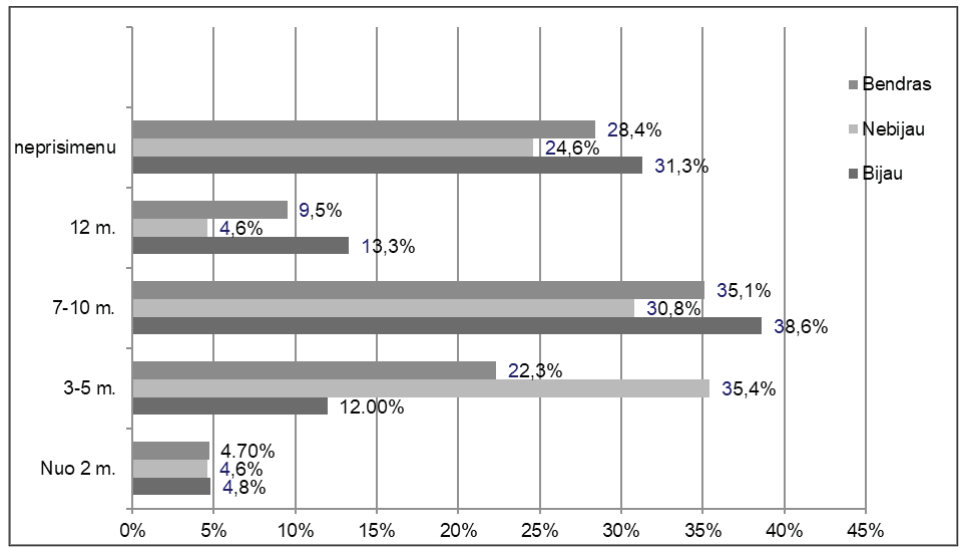

2 pav. Suaugusiųjų dantų gydymo baimès priklausomybė nuo pirmo vizito pas odontologą. 
tamas gydytojas, 6,8 proc. apsilankius naujoje klinikoje.

50,7 proc. pacientų daugiau bijo šalinti dantis, 32,4 proc. - gręžti dantis, 3,4 proc. protezuoti ir 12,2 proc. - visko. 51,4 proc. prašo nuskausminti. 73 proc. atsakè, kad baimé būna mažesnè, jeigu gydytojas viską smulkiai paaiškina. 47,3 proc. baimè padidejja, kai reikia ilgai laukti ir 41,9 proc. - kai šalia laukia blogai nusiteikusių pacientų.

Apklaustiesiems, kurie bijo dantų gydymo, statistiškai reikšmingai darėsi silpna 7,2 proc. ir dažniausiai norèjosi išvengti vizito 62,7 proc. $\left(\chi^{2}=19,66\right.$, $11 \mathrm{~s}=4, \mathrm{p}<0,001) .21,7$ proc. bijančiujų didžiausia baimè buvo pirmo apsilankymo metu $\left(\chi^{2}=18,912,11 \mathrm{~s}=5, \mathrm{p}<0,05\right)$. Bijantys 18,1 proc. statistiškai patikimai bijojo visų procedūrų $\left(\chi^{2}=14,022,11 \mathrm{~s}=4, \mathrm{p}<0,05\right)$ [4pav.]. Skirtumo tarp paskutinès patirties, kaip dažnai prašo nuskausminti ir baimès nebuvo.

59,0 proc. bijančiujų padidèdavo baimé, kai ilgai reikia laukti vizito $\left(\chi^{2}\right.$ $=10,447,1 l s=1, p<0,01)$. Ir 49,4 proc. bijančiujų baimé padidèdavo, kai greta laukia ir blogai nusiteikusių pacientu $\left(\chi^{2}=0,002,11 s=1, p<0,01\right)$.

Šiek tiek daugiau moteru 57,3 proc. nei vyrų 53,8 proc. jautė dantų gydymo baimę, bet skirtumas nebuvo reikšmingas. Tik 2 proc. daugiau bijojo rajono gyventojų ( 57,4 proc.) nei miesto gyventojų (55,4 proc.). Statistiškai patikimo skirtumo nestebejome tarp apklaustujų išsilavinimo, gyvenamosios vietos. 71,4 proc. bijojo išsiskyrę, 54,3 - vedę ir 51,7 proc. vieniši asmenys.

Daugiausia gydymo bijojo 25-34 metų amžiaus grupès žmonès - 66,7 proc., 24 ir $<$ metų pacientų grupejje $-38,7$ proc., $35-44$ metų $-55,1$ proc., 44 ir $>$ metų $-52,9$ proc. Pagal apsilankymų priežastị 54,3 proc. vyriausios grupès pacientų lankėsi, kai atsirasdavo skausmas, 24 ir $<$ metų grupés pacientai statistiškai reikšmingai lankèsi 2 kartus per metus ir 35-44 metų - 20,4 proc. lankèsi kas 2 metai $\left(\chi^{2}=25,441,11 s=12, p=0,013\right)$. 67,7 proc. 24 ir $<$

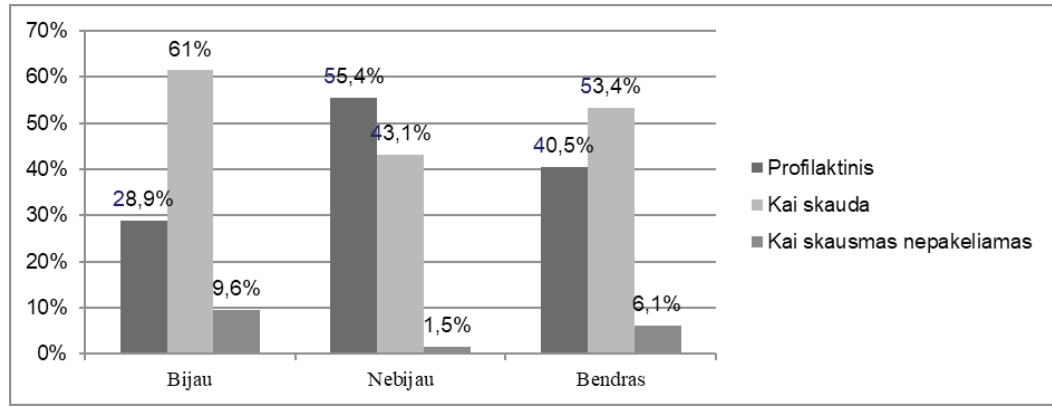

3 pav. Suaugusiujų dantų gydymo baimès ir vizitų priežasties priklausomybè.

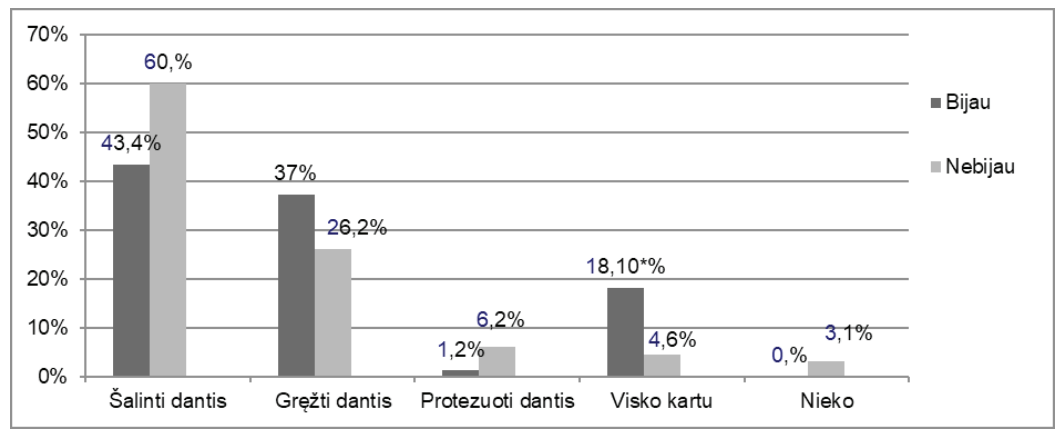

4 pav. Suaugusiujų pasiskirstymo priklausomybè nuo baimės ir atliekamos procedūros. m. pacientų vizitas būna profilaktinis, 72,7 proc. $25-34 \mathrm{~m}$. - kai skauda $\left(\chi^{2}=20,507\right.$, $11 \mathrm{~s}=6, \mathrm{p}<0,05)$.

Didžiausią baimę pacientai jautė matydami adatą 56 proc. (iš jų net 16,2 proc. labai didelę baimę) ir jausti ịdūrimą - 69 proc. (iš jų labai didelę baimę - 18,2 proc.).

\section{Rezultatų aptarimas}

Atliekant ši tyrimą siekta išsiaiškinti, kokie veiksniai sąlygoja suaugusių pacientų dantų gydymo baimę.

Dantu gydymo baimė yra opi problema, kuri būdinga didžiajai daliai visuomenès narių. Kai kurių autorių teigimu, paplitimas svyruoja nuo 4 iki 20 procentu pasaulyje $[6,12,13]$. Švedijoje nuo stiprios baimès kenčia 4,7 procentai žmonių [14]. Yra irodyta, jog moterys dažniau bijo odontologinių procedūrų, nei vyrai [15], bet mes statistiškai reikšmingo skirtumo nenustatėme, nors bijančių moterų 5 procentais buvo daugiau nei vyrų. Mūsų atlikto tyrimo rezultatai parode, kad dantu gydymo bijo daugiau nei pusè apklaustųjų ir dešimtadalis patiria labai didelę baimę. Didžioji dalis pas odontologus lankosi tik tada, kai skauda arba skausmas būna nepakeliamas. Kaip pagrindines priežastis, kodèl pacientai praleidžia profilaktinius vizitus, Trandan S. ir kitų atliktame tyrime Jungtinèje Karalystèje nurodè nenumatytas aplinkybes, dantu gydymo baimę, nepatogų susisiekimą su klinikomis, užmaršumą ir tingumą [16]. Taip pat Holtzman ir kiti nustatè, kad dèl dantų gydymo baimés pacientai 3 kartus dažniau praleidžia vizitus nei tie, kurie nebijo [17].

Vertinant baimę ir žmogaus amžių, pastebejjome, jog labiausiai bijo 25-34 metu žmonès (net 66,7 proc. iš visų tirtujų šioje amžiaus grupejje), lyginant su Australija, kur didžiausia bijančių dantų gydymo pacientų populiacija nustatyta 35-44 metu amžiaus grupejje (19,7 proc.) [18]. Tačiau Holtzman ir kiti teigia, jog baimè su amžiumi mažèja, nes vyresnio amžiaus pacientai sugeba suvaldyti savo baimes [17].

Dažnai pacientai bijo dantu gydymo proceso (šaknies kanalų gydymo ar dantų šalinimo) ir dèl to vengia lankytis pas odon- 
tologą [19]. Mūsų atliktas tyrimas taip pat patvirtino faktą, kad labiausiai pacientai bijo dantų šalinimo - net 50,7 proc. iš visų apklaustujjų. Tačiau kiti šaltiniai teigia, jog labiausiai pacientams kelia nerimą dantų gydymo kaina, injekcijos ar skausmingos procedūros [6]. Kalbejjimas ir supažindinimas su būsimomis procedūromis, detalus jų apibūdinimas gali nuraminti pacientą, taip teigia 73 procentai mūsų apklaustụjų, kurie jaučia didelę dantų gydymo baimę. Cobbar ir kitų tyrimo rezultatai tam prieštarauja - detalus raštiškas chirurginès procedūros aprašymas nerimo pacientams nesumažino [20].

Vienas pagrindinių baimę pacientams keliančių veiksnių yra injekcijos ir joms naudojamos adatos. Dauguma pacientu nemégsta injekcijos dèl sukeliamo nutirpimo jausmo. Kai kurie odontologai netgi naudoja anestetikus be vazokonstriktoriaus, kad anestezijos laikas būtų trumpesnis [21]. Mūsų tirtieji pacientai dažniau prašè nuskausminimo (51,4 proc.), tačiau net 56 procentai apklaustujų patvirtino bijantys matyti adatą, o 69 - jausti adatos ịdūrimą.

\section{Išvados}

56,1 proc. apklaustujų patiria odontologinę baimę, iš jų net 9,5 proc. - labai stiprią baimę, dèl kurios vengia odontologinių procedūrų. Lytis, išsilavinimas, gyvenamoji vieta neturejo įtakos baimei. Odontologinei baimei įtakos turejjo amžius, šeiminè padètis, pirmas vizitas pas odontologą. Baimè reikšmingai padidèja, kai reikia ilgai laukti ir šalia yra blogai nusiteikusių pacientų. 61,4 proc. bijančiųų kreipiasi, kai skauda, 9,6 proc. - kai skausmas yra nebepakeliamas. Daugiausia žmonių bijo šalinti, gręžti dantis, matyti adatą ir jausti adatos įdūrimą.

\section{Literatūra}

1. Steven Taylor. Anxiety sensitivity: theory, research, and treatment of the fear of anxiety. 1 ed.Routledge, 2014; 384.

2. Youn-Soo Shim, Ah-Hyeon Kim, Eun-Young Jeon, So -Youn An. Dental fear \& anxiety and dental pain in children and adolescents; a systemic review. Dental Anesthesia and Pain Medicine 2015; 53-61.

3. Peltier B. Psychological treatment of fearful and phobic special needs patients. Spec Care Dentist 2009; 29(1):51-57. https://doi.org/10.1111/j.1754-4505.2008.00062.x

4. Heyman RE, Slep AM, White-Ajmani M, Bulling L, Zickgraf HF, Franklin ME, Wolff MS. Dental fear and avoidance in treatment seekers at a large, urban dental clinic. Oral Health Prev Dent 2016; 14(4):315-20.

5. Tickle M, Jones C, Buchannan K, Milson M.K, Blinkhorn S.A, Humphris M.G. A prospective study of dental anxiety in a cohort of children followed from 5 to 9 years of age. International Journal of Paediatric Dentistry 2009; 19:225-232. https://doi.org/10.1111/j.1365-263X.2009.00976.x
6. Armfield JM. The extent and nature of dental fear and phobia in Australia. Aust Dent J 2010 Dec; 55(4): 368-77. https://doi.org/10.1111/j.1834-7819.2010.01256.x

7. Armfield JM, Spencer AJ, Stewart JF. Dental fear in Australia: who's afraid of the dentist? Aust Dent J 2006 Mar; 51(1):78-85. https://doi.org/10.1111/j.1834-7819.2006.tb00405.x

8. Heidari E, Banerjee A, Newton JT. Oral health status of nonphobic and dentally phobic individuals; a secondary analysis of the 2009 Adult Dental Health Survey. Br Dent J 2015 Nov $13 ; 219(9)$. https://doi.org/10.1038/sj.bdj.2015.853

9. Liinavuori A, Tolvanen M, Pohjola V, Lahti S. Changes in dental fear among Finnish adults: a national survey. Community Dent Oral Epidemiol 2016 Apr;44(2):128-34.

https://doi.org/10.1111/cdoe.12196

10. Kleinknecht RA, Thondike RM, McGlynn HD, Harkavy L. Factor analysis of the dental survey with cross-validation, Journal of the American Dental Association 1984; 108: 59-61. https://doi.org/10.14219/jada.archive.1984.0193

11. Pukènas K. Kokybinių duomenų analizè SPSS programa: mokomoji knyga. Kaunas: Lietuvos kūno kultūros akademija, 2009; 24-32.

12. Gatchel RJ, Ingersoll BD, Bowman L, et al. The prevalence of dental fear and avoidance: a recent survey study. J Am Dent Assoc 1983;107:609-610.

https://doi.org/10.14219/jada.archive.1983.0285

13. Hill KB, Chadwick B, Freeman R. et al. Adult dental health survey 2009: relationships between dental attendance patterns, oral health behaviour and the current barriers to dental care. $\mathrm{Br}$ Dent J 2013; 214:25-32. https://doi.org/10.1038/sj.bdj.2012.1176

14. Svensson L, Hakeberg M, Boman UW. Dental anxiety, concomitant factors and change in prevalence over 50 years. Community Dent Health 2016;33:1-6.

15. Smyth JS. Some problems of dental treatment. Part 1. Patient anxiety: some correlates and sex differences. Aust Dent J 1993;38:354-359. https://doi.org/10.1111/j.1834-7819.1993.tb05516.x

16. Tandon S, Duhan R, Sharma M, Vasudeva S: Missed dental appointments between the cup and the lip: missed dental appointments. J Clin Diagn Res 2016; 10:122-124.

17. Holtzman JM, Berg RG, Mann J, Berkey DB. The relationship of age and gender to fear and anxiety in response to dental care. Spec Care Dentist 1997; 17: 82-7. https://doi.org/10.1111/j.1754-4505.1997.tb00873.x

18. Thomson WM, Stewart JF, Carter KD, Spencer AJ. Dental anxiety among Australians. Int Dent J 1996;46:320-324.

19. Standards for the dental team. General Dental Council. 2013, Accessed: February 9, 2018.

20. Cabbar F, Burdurlu MÇ, Tomruk CÖ. Does giving brief information keep patients calm during different oral surgical 
procedures? Quintessence Int 2018 Apr; 16:1-12.

21. Armfield JM, Milgrom P. A clinician guide to patients afraid of dental injections and numbness. SAAD Dig. 2011 Jan;27:33-9.

\section{INDICATORS AFFECTING DENTAL FEAR IN \\ ADULTS}

K.Vasiliauskas, K.Klasavičiūtė, I.Vasiliauskienė, V.Andruškevičienė, K.Saldūnaitė, E.Slabšinskienè

Key words: dental fear, dentist fear, dental anxiety.

Summary

The aim. To evaluate and find out the main factors affecting dental fear in adults.

Methods. One time trial was carried out in Kaunas Centre and Vilkaviškis Primary Health Care Centre. Patients were given questionnaires consisting of 4 questions: demographic characteristics, behavioral, socio-economic factors. Statistical data analysis was performed using SPSS 22.0 program. Results were statistically significant when $\mathrm{p}<0.05$. The significance of statistical results were determined using chi-squared $\left(\chi^{2}\right)$ criterium.

Results. The study involved 148 patients: 96 women and 52 man. More than half of the respondents $(55,9 \%)$ have dental fear,
$9.5 \%$ - have high fear. Women has bigger dental anxiety than man. Divorced people $(71,4 \%)$ are more likely to be afraid than married or lonely persons. Patients would visit their dentists more often when feeling pain. The most common body reaction is desire to avoid a visit to the dentist. The biggest fear is to see the needle according to $56 \%$ respondents. Most respondents feel dental fear every time they come to the dentist or need to have tooth extraction.

Conclusions. 56.1\% respondents have dental fear, 9.5\% - very strong fear leading to avoiding dental procedures. Gender, education, place of residence had no effect on fear. Age, material status, first visit experience had impact on dental fear. Dental fear increases when you are waiting for a long time for a visit or there are some disgruntled people in the same room. $61.4 \%$ persons visit dentist only when they feel pain and $9.6 \%$ of them - when pain is no longer tolerable. Most people are scared of tooth drilling, tooth extraction and needles.

Correspondence to: klasaviciutekristina@gmail.com

Gauta 2018-11-05 